\title{
Global Market and Public Governance in Europe
}

\author{
Luca Bisio*
}

\begin{abstract}
The relationships between the governance of public bodies and stakeholders is of essential importance, independently of the different administration systems existing in Europe.

Therefore the Nation-States are: losing power while maintaining considerable influence; trying to govern the complex dynamic balance between global network pressure and the growing press on local identities.

In this scenario, answers coming from Nation-States on governance models go in the dual direction of: developing supra-national institutions to retake their role with respect to global networks; decentralising administrative power to a regional and local level, so to reaffirm their internal legitimacy.
\end{abstract}

Keywords: Public Governance; Nation-States; Stakeholders; European Union Governance Principles; Global Markets

\section{Principles of Public Governance in Europe}

The importance of what has emerged from studies on corporate governance in the private sector has caused the debate to widen progressively and extend to public administration governance problems. In particular, the problem of relationships between government, departments, public bodies and stakeholders (both inside and out) is of essential importance, independent of the different administration systems existing in Europe.

This is true for:

- the Italian system (and others similar) where the vertical and horizontal 'subsidiarity' principle ${ }^{1}$ is applied extensively and the distinction between policy, control (political authority realm) and management functions (assigned to management) seems to be deep rooted, at least from a regulatory point of view;

- the French model, where managerial power is in the hands of mayors and the degree of administrative decentralisation is not that well developed especially if compared to Germany where the weight of lands is

*Lecturer in Management, University of Milan-Bicocca (luca.bisio@unimib.it) 
considerable and local administration, already assigned their own functions, can intervene following further delegation from the lands themselves.

\subsection{European Commission principles}

The first step towards handling governance at a supra-national level was taken by the European Community Commission which announced five governance principles (Figure 1) in a White Paper. This intended to create 'the foundations for democracy and legality in member States' and can be applied 'at all government levels: global, European, national, regional and local'. Above all, it established that institutions must operate in a more open manner, must make an active effort to better explain, using accessible, understandable language for the general public, what the EU does and what the decisions it makes consist of. It must, therefore, increase citizens' faith in complex, difficult to 'read' institutions ('Openness' Principle).

Figure 1: European Union Governance Principles

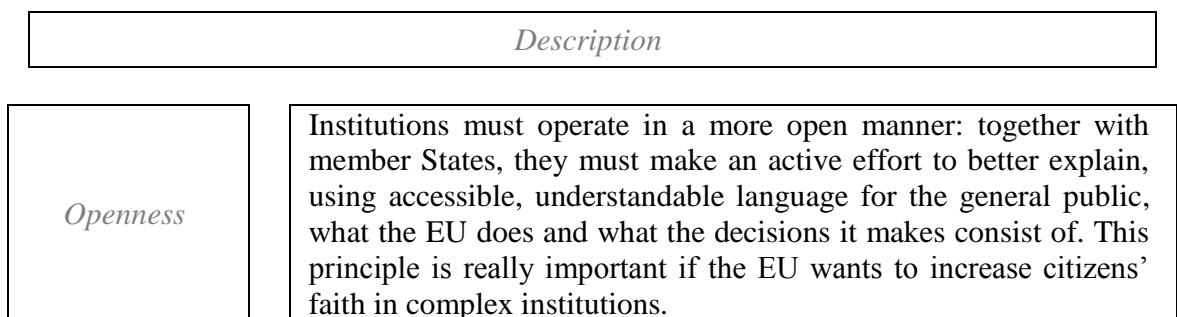

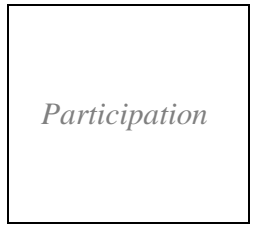
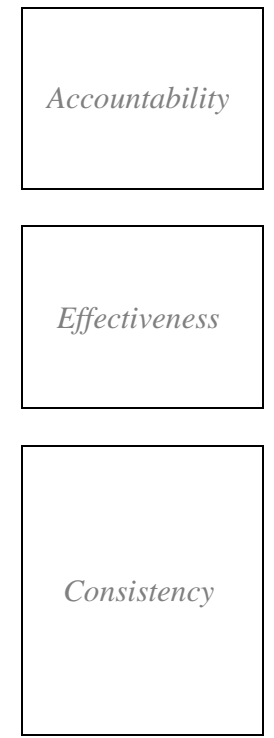
faith in complex institutions.

Quality, pertinence and effectiveness of EU policies depend on generating ample participation during their lifetime, from first draft to implementation. Greater participation will increase faith in the final result and in the institutions issuing the policies. For greater participation, central administration must try to involve citizens in drafting and implementing EU policies.

Roles within legislative and executive processes must be defined more clearly. Each EU institution must explain its role in Europe and be accountable for it. There is a need for greater clarity and responsibility from member States and from all those taking part at all levels in drafting and implementing EU policies.

EU policies must be effective and timely, producing the results required based on clear targets, assessing their future impact and, where possible, past experience. In order to be effective, policies need to be applied proportionally and decisions made at the most opportune level.

EU policies must be consistent and easy to understand. There is a growing need for consistency: ever more tasks have to be done. A wider EU will increase the differences; challenges such as climate change and demographic decline go beyond the borders of those sector polices the EU was built on. Regional and local authorities are becoming more and more involved in EU policies. Consistency needs political leadership and institutions taking responsibility in a decisive manner to ensure consistency within a complex system.

Source: European Commission Governance White Paper, Brussels, 2001. 
Second, emphasis is placed on how the quality, pertinence and effectiveness of EU policies depend on the ample participation they generate during their lifetime, from first draft to implementation. The greater the participation, the more faith exists in the final result and in the institutions issuing policies ('Participation' Principle).

The accountability concept is no less important. Roles within legislative and executive processes must be defined more clearly. Each EU institution must explain its role in Europe and take responsibility for it. However, there is a need for greater clarity and responsibility from member States too, and from all those involved at all levels in drafting and implementing EU policies ('Accountability' Principle).

Responsible action must lead to the drafting of effective, timely policies producing results required based on clear targets, on assessing their future impact and, where possible, on past experience. In order to be effective, policies need to be applied proportionally (tools suited to the purpose) and decisions made at the most opportune level ('Effectiveness' Principle).

Finally, the Commission places emphasis on the fact that EU policies and intervention be consistent and easily understandable. This is motivated by the fact that there are ever more tasks to be implemented, EU widening will increase differences. Regional and local authorities are getting increasingly involved in EU policies ('Consistency' Principle).

When the Principles are first read, one can see how, alongside the oft repeated need to promote greater visibility for community institutions ${ }^{2}$, strong emphasis is placed on three basic concepts that should inspire the actions of each public administration level.

In particular:

- effectiveness and timeliness of administrative actions, to produce results easily comparable with purpose and targets set and focussing on the impact caused and not on the amount of product/service provided;

- transparency of and participation in decision-making processes and related application as they are considered a lever maximising the effect of public policies;

- responsibility as a basis for one's degree of accountability.

However, it can be seen how the principles in question concentrate on:

- 'company-like' aspects (search for effectiveness, efficiency, transparency etc.);

- a European governance context closely linked to solving internal problems and not too focussed on, if we do not consider the declarations of principle, the EU contribution to global public governance development.

\subsection{Determining Aspects of how Public Administration Functions}

In order to analyse how public administration functions and to try and identify governance principles that are not just 'adapted' from private reality models, the link between institutional system, political system and company system must be considered as these are essential influencing factors (Figure 2). 
Figure 2: Determining Aspects of how Public Administration Works

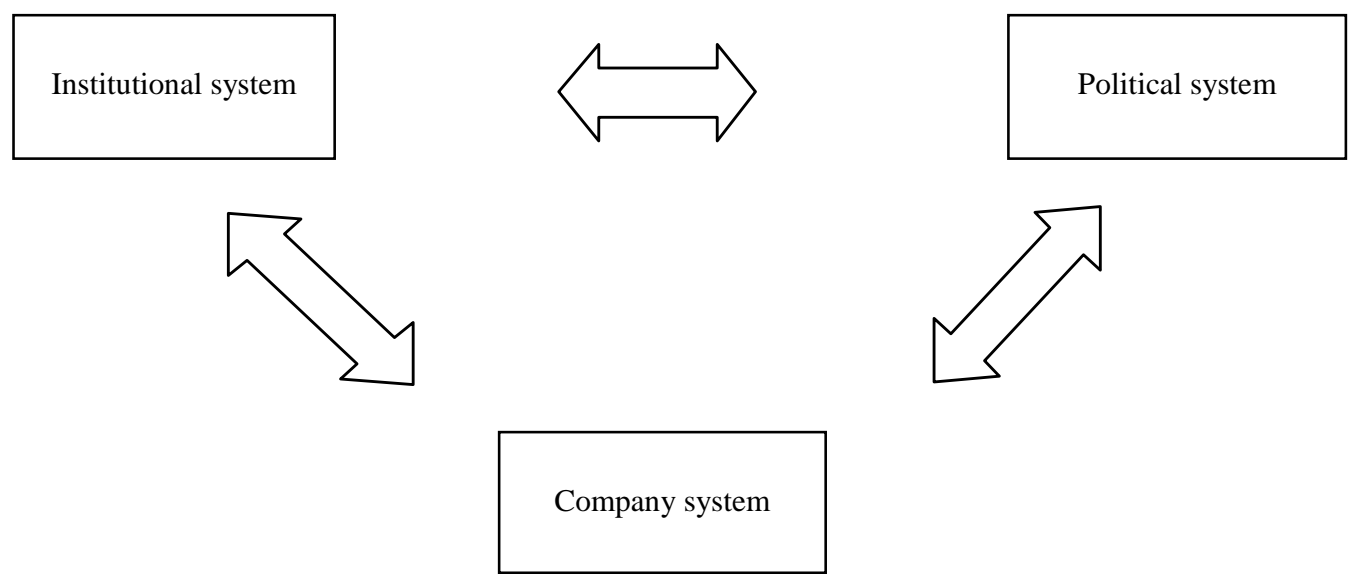

These systems make up the principles, rules and instruments:

- ensuring the balance between different bodies and respect for rights and duties inherent in relations with citizens and other juridical subjects $\rightarrow$ institutional system;

- through which different social interests approach one another (voting system, public party financing, etc.) $\rightarrow$ political system;

- regarding activities targeted to satisfy collective needs using administration resources $\rightarrow$ company system ${ }^{3}$.

It is clear that public administration does not move in a company system, however it is 'both political institution and company'. Some features identifying influence over governance can be identified.

\section{Public administration as a weakly linked system}

Public administration is made up of number of bodies which have to satisfy 'public needs'. Alongside representative and political functions, these bodies exercise an economic function providing production/supply of goods and services 'not for sale' and at least partially unbound by the market ${ }^{4}$.

The reasons why public administration exists are therefore linked to:

- evident collective needs, not entirely pre-determined but dependent on both historical and contingent conditions;

- the need to single out, promote and implement better ways to satisfy these needs, combining the resources and skills of the different public and private players present in society.

The degree of economic effectiveness and social acceptability created by the fact that public bodies carry out specific activities instead of other alternative intervention modes is also part of these reasons ${ }^{5}$. In other words, it can be said that public, collective needs definitely exist in all societies, however they cannot be defined in a rigid, deterministic manner. They represent complex, variable human and social results. Some needs can be called 'public' as public bodies and institutions have proved their ability to intervene in a way preferable to other available alternatives ${ }^{6}$. 
Hence public administration must be considered a combination of bodies linked to varying degrees, however all with mutual autonomy. This reality is decidedly different from the picture of public administration as an entity or unitary subject and as a 'system' in the strong sense. It is thus a sum of coordinated elements integrated by a 'centre', the expression of single, well defined objective. It can be considered as an approach to a 'weakly connected system' with institutions and their own independent goals taking part. This view has a stronger basis today as the political-institutional system model leans towards federalism and subsidiarity, and towards acknowledging vast areas of independence, decision-making and administrative decentralisation for local and regional institutions ${ }^{7}$.

This outlook shows that European Commission determinations are, on the one hand, essential however, at the same time, they need to reflect greater analysis of institutional, political and company systems.

\section{Institutional system}

At an institutional system level, relationships between European institutions must be reconsidered as they are still based on traditional Nation-State operating mechanisms. The so-called "community method" ${ }^{8}$ suffers from complexity caused by the need to represent, at institutional level, two different legislative power spheres: the citizens' legislative power sphere (European Parliament) and the member States' legislative power sphere (Council of Ministers). This inevitably creates the need to regulate power relations between these two bodies (with the parliamentary side often in a weak, subordinate role) and between them and the European Commission. This problem leads to the complexity and inertia of decision-making processes and reflects on relations between European and national, regional and local institutions.

\section{Political system}

At a political system level, the Parliament role and function need to be considered. The direct citizen representation European institution (thus, at least theoretically, it should be closer to them), besides suffering from the same problems affecting local and national elected assemblies (summed up in the inability to effectively exercise an effective, timely leadership and political control role), still suffers from problems with its supra-national institutional make-up:

- low effective representation in Parliament of European citizens' interests as European parties are incapable of being a dialogue and direct aggregation channel. These political groupings are created by putting existing traditional parties in the different States together and do not get direct citizen consent and legitimisation. Citizens often do not know they exist. Because of this, parties cannot put forward a clear, visible European political project;

- furthermore, one can still see a clear pre-eminence of national over European interests in the creation of electoral consensus mechanisms. This is demonstrated by:

- messages from the various political forces during campaigns in the recent European elections, all generically tending to support national interests in Europe instead of proposing European level solutions and projects; 
- the really rare cases of European member candidates being elected in state constituencies that are not in their state of origin.

These irregularities directly involving the European Parliament are joined by more general considerations on how citizens take part in European decisionmaking. Here it ought to be said that citizens, besides being very rarely involved, still take part as citizens belonging to EU states and not as 'Europeans'. A clear example of this comes from how the European Constitution is approved. A Constitution on which not all Europeans are called to express a vote as whether they should be involved through referendum has been left to the discretion of individual member countries. Hence the French can be called on to express themselves over the constitutional Charter but not the Italians. This example, along with all the other situations when election results were considered as the sum of individual member state results instead of a European level choice process, leads one to think that the EU is still more of a 'State democracy' rather than a 'citizens' democracy'.

\section{Company system}

At a company system level, the political-institutional system model pushing towards federalism and subsidiarity generates three integration needs:

- different government levels present in the same area (EU, State, regions, local authorities) need to be governed. This creates the risk of overlapping intervention. This split can be motivated by different needs to be satisfied or by several levels present in a need satisfaction action, typically, a stage defining general conditions and principles of public intervention in a certain problem area followed by a concrete organisation, service and intervention management stage ${ }^{9}$;

- other important strategic and organisation integration problems involving public institutions at the same level finding themselves operating in adjoining spaces. This problem, traditionally involving local authorities belonging to the same geographical area within a state, is becoming important for relations between local authorities and regional governments belonging to adjacent geographical areas but subject to the sovereignty of different states;

- a further important inter-institutional integration need concerns policies and intervention by different authorities in the same social area. This is the case for a lot of social intervention where problems affect territories with different institutions and require joint operations from public and private bodies operating in a specific sector. This kind of inter-institutional relationship also considers relations between public and private sectors when handling social problems, and is becoming more important because of the complexity and interdependence of need situations the public sector has to deal with.

The social and economic complexity of problems created by society means abandoning rigid, institutional frameworks. These are based on increasing and multiplying general coordination super-organisations with a tendency for formal control and authorisation, and hierarchical domination of central government over local authorities. This is a model that traditionally characterises Nation-State 
governance systems and which has often been transferred to European institutional operating mechanisms.

In this situation, there must be a move towards governance systems giving greater priority to flexible operating mechanisms to govern relationships between the different 'public arena' players.

Thus, the importance of inter-institutional relations leads to placing individual public authority action within joint strategies and action lines to handle common problems. These strategies are often not formalised and evolve continuously. They should lead to dialogue, exchange and integration processes between public institutions (at different levels) and the various social partners. This would be based on rationalised decision-making procedures shared by all players called to choose, draft and implement strategies.

These decision-making procedures become an essential integration and coordination tool. They flank a lean, clearly-defined public player system, with no multiplying of decision-making levels and intermediate authorities, and are able to talk with all interested parties effectively ${ }^{10}$.

In a context of this kind, what is common to all different administrations and what makes them 'a system' is the will to create public value ${ }^{11}$, to satisfy all interested party needs. This results from the fact that administration legitimisation comes from the capacity to create value for society, and get results that are worth at least as much as the resources used and personal freedom restrictions involved.

All this shows the complexity involved in integrating organisations that are goalwise 'unitary' but weakly connected to one another: with variations in electoral systems and cycles, and with organising player roles that are not always accepted and at times difficult to interpret.

\subsection{The Limits of a Eurocentric View}

The second governance element to be analysed, according to the European Commission, is the need to consider principles defined for member states within a 'global' context.

Reading the White Book highlights awareness that the EU must cut itself a role within the world governance debate. However, solutions proposed do not go much beyond the need to 'fully acknowledge the importance of the world dimension', to strengthen 'its own voice in multilateral negotiations' and the awareness that 'the EU must speak as one: must strengthen representation in international and regional arenas, even on economic, financial governance, the environment, development and competition policies ${ }^{12}$.

The lack of more specific direction on influencing the global aspect of public governance is mainly due to the strategic orientation outlined in the White Book. Orientation by which 'the Union's first step must be to successfully implement governance reform at home, and then push for changes at international level ${ }^{13}$.

Furthermore, an approach of this kind, definitely valid at the time the White Paper was published (August 2001) can now no longer be considered viable following September the $11^{\text {th }}$. That led to an even more pressing need for the European Union to take on a strong, clearly acknowledged player role over global problems. Problems that need to be handled multilaterally mean coordinating the actions of different states (with resulting sovereignty limits) and strengthening the credibility of international agreements and institutions ${ }^{14}$. 
From this point of view, the outlook is changing rapidly; hence global reality interpretation models in which public institutions operate have to be re-thought.

Let us start from a statement that was valid for a long time: 'the specificity of a capitalist State lies in the fact that it absorbs social time and space, determines space-time matrices and monopolises time and space organisation', turning them into dominion and power networks through its action. Thus the modern nation proves to be a product of the State ${ }^{15}$. If a concept like that could have been shared at some point, today we can say that 'State control over space and time is bypassed more and more by the global flow of capital, goods, services, technology, communications and information ${ }^{16}$.

'Global networks operating in widened competitive spaces (adding value to and exploiting intangible assets, brand assets, information systems and company culture) have access to market information that is so extended and sophisticated that they often find themselves contending as the driver of who sets local development guidelines with governments ${ }^{17}$.

We therefore find ourselves faced by a Nation-State that is:

- losing power while maintaining considerable influence;

- trying to govern the complex dynamic balance between global network pressure and the growing push from local identities.

In this framework, answers coming from Nation-States on governance models go in the dual direction of:

- developing supra-national institutions to retake their role with respect to global networks;

- decentralising administrative power to regional and local level, thereby restating their 'internal' legitimacy.

The 'global' outlook in which governance philosophy is growing is outlined below. Promoting the vision 'going beyond the Union' is still not clearly outlined when reading the European Commission principles.

\section{Difficulties lying behind 'European' Governance}

The need for a global vision is motivated by pressure exogenous factors place on individual Nation-States. These, on the one hand, are difficult to govern and, on the other, cross European borders and becoming part of the whole globalisation process. Let us endeavour to analyse some reasons for the Nation-State weakness.

\section{Critical economic policy aspects in government}

Individual Nation-States are losing and will go on losing direct control over their economic policies ${ }^{18}$. Within the Union, the Central European Bank decides on monetary policies and related reference rates. Individual State intervention autonomy is limited to deciding on expenditure within specific macro-economic parameters set by the monetary authority.

At the world level, we are faced by an essential link between the dollar, yen and Euro - a link creating a basic element in maintaining currency market balance and, consequently, that of investments and global commerce. It is obvious that if the 
exchange rate is systematically dependent so are - one after the other - monetary policies, prime rates and budget policies.

All this is associated with:

- production trans-nationalisation and the resulting inability of NationStates to maintain the productive base needed to create revenue within their borders;

- the national tax system basis.

In a context such as this, it is difficult to speak of 'full' individual Nation-State control over economic policies.

Dependence on global financial markets

Analysis of macro-economic data ${ }^{19}$ highlights two trends:

- despite public needs and regulating functions having less weight, States maintain an important role within the global system. This leads to having to cover expenditure with tools that are not only tax based;

- these needs mean growing use of foreign loans.

Hence, as a whole, the intertwining national economies and Nation-State financial dependence on global markets and on capital flowing in from 'outside borders', have created the conditions for an international-level fiscal Nation-State crisis.

\section{Welfare state crisis}

Over the last fifty years, European states have been legitimised through welfare policies adopted - policies that are now becoming more and more difficult to defend.

Global enterprises find themselves operating in a context where the critical success factor becomes manufacturing in countries where low labour costs, weak, non-existent safety regulations and environmental 'non-policies' ensure maximum cost containment. In addition, the quality superiority of labour present in advanced economies is no longer important and prohibition policies that once raised the cost of imported products are no longer effective.

'In an economy where basic capital, goods and services markets are well integrated globally, there is not much space left for social policies that really differ from one another (and above all, of great importance), given the relative equality of labour productivity levels and production quality'. Welfare, to survive, must link itself more to growth in productivity (in production, information and knowledge terms) to create a virtuous circle between social investment and economic development.

The state must encourage development, and thus welfare, through a difficult, innovative interface role between 'nation' needs and the global context it is forced to be part of.

\section{Loss of control over media and communications}

'Control over information and events - and through them also opinions and images - was the main state power tool, destined to be perfected in the mass media $\mathrm{era}^{20}$. 
Today, the Nation-State is faced with three situations undermining that power:

- globalisation and interlinked ownership outside of individual State control;

- technology flexibility and pervasiveness making it impossible to regulate and control information completely;

- media autonomy and variety. Growth in local and regional media strengthens its role and makes it a player other media must relate to.

In addition, diversification in communication modes, media linked together in digital hypertext, the impossibility of full control over satellites and computer communications have made traditional forms of control and regulation obsolete. 'Nowadays media is of greater importance when its shows its independence. We can say that 'globalisation/localisation of media and electronic communication correspond to the denationalisation and outing from state control of information, with the two trends not, as yet, separable ${ }^{21}$.

\section{Globalisation of organised crime}

Concerning the problem of organised crime and individual Nation-State strength/weakness against it, the most critical element is not its pervasiveness or impact on politics but the presence of global organised crime links and their capacity to influence international relations (economic and political) resulting from the size and dynamism of the criminal economy. This leads to the risk of NationState de-stabilisation caused by various crime businesses - from trafficking in drugs, arms, technology and organs to slave trafficking and the introduction of new, organised forms of slavery.

The impact of crime globalisation on Nation-States involves (and weakens) them in three ways:

- the degree organised crime has infiltrated the different State structures and levels (central, regional or local);

- quality and effectiveness of cross-border relations depending on the degree of crime fighting cooperation between them;

- weight of financial flow from criminal sources on the entire Nation-State economy.

\section{Public Governance Prospects in Europe}

The above consideration seems to highlight the need for some sort of European State governance that, though inspired by European Commission Principles, crosses continent borders so as not to be overwhelmed by exogenous push along with endogenous problems. Endogenous problems come specifically from creating new supra-national institutions (at European level) and from centrifugal processes started by administrative decentralisation strengthening regions and local authorities.

At a global level, (thus exogenous from our 'European' observation point), the greater risk is that of a definitive move from USA-USSR bi-polarism in managing world balance to 'unilateralism' exercised by the United States exceeding any potential multilateral power Europe is making an effort to achieve. 
The main challenge to multilateralism comes from the US, even more so following September the $11^{\text {th }}$. This is because the USA is a military superpower, the second biggest economic region in the world and still the main production centre for knowledge and technology innovation. American unilateralism, highly evident in environmental policies (see non-ratification of the Kyoto protocol), in commercial policies and, above all, in military aggression, introduces a basic contrast within the international system. While issues are inter-dependent, managing them suffers from the unilateral American approach in imposing its hard power even at the cost of exhausting its soft power credit (cultural influence) ending up by destabilising that multilateral interaction which world balance depends on ${ }^{22}$.

If Europe really wants to pick up the globalisation challenge by 'becoming the world's most competitive, dynamic knowledge economy, able to grow economically in a sustainable manner, accompanied by improved quantitative and qualitative employment and greater social $\operatorname{cohesion}^{23}$, it must become the main player in building new global governance by:

- trying to lead USA unilateralism towards multilateral confrontation, and giving space and credibility back to international institutions;

- giving meaning to governance principles declared by individual NationStates.

\section{Bibliography}

Airoldi G., Brunetti G., Coda V., Lezioni di economia aziendale, Il Mulino, Bologna, 1994.

Borgonovi E., Principi e sistemi aziendali per l'amministrazione pubblica, EGEA, Milan, 2002.

Bouckaert G., Pollitt C., La riforma del management pubblico, EGEA, Milan, 2002.

Brondoni S. M., Ouverture de 'Market-Space Management', Symphonya. Emerging Issues in Management (symphonya.unimib.it), n. 1, 2002.

http://dx.doi.org/10.4468/2002.1.01ouverture

Business Week, The Future of Money, (12 June 1995).

Cairoli M.G., Globalizzazione e localizzazione delle imprese internazionalizzate, Franco Angeli, Milan, 2000.

Castells M., Il potere delle identità, Università Bocconi Editore, Milan, 2003.

European Community Commission, European Governance: a white paper, Brussels, 2001.

de Woot P., The Challenges of Economic Globalisation: Business, Competion and Society, Symphonya. Emerging Issues in Management (symphonya.unimib.it), n. 2, 2002.

http://dx.doi.org/10.4468/2002.2.03dewoot

Golinelli G., L'approccio sistemico al governo dell'impresa. Volume 1, L'impresa sistema vitale, Cedam, Padua, 2000.

Habermas J., Cittadinanza politica e identità nazionale. Riflessioni sul futuro dell'Europa, in Habermas J., Morale, diritto, politica, Edizioni di comunità, Turin, 2001.

Lambin J.J., Il Strategic Marketing Revisited after September 11, Symphonya. Emerging Issues in Management (symphonya.unimib.it), n. 1, 2002.

http://dx.doi.org/10.4468/2002.1.02lambin

Mattelart A., La comunicazione mondo, Il saggiatore, Milan, 1994.

Moore M. H., Creating Public Value, Harvard University Press, Cambridge Mass, 1975. 
Poulantzas N., Il potere della società contemporanea, Editori Riuniti, Rome, 1979, p. 109.

Prentice D.D., Some aspects of the Corporate Governance Debate, in Prentice D.D., Holland P.R.J. Contemporary Issues in Corporate Governance, Oxford, Clarendon press, 1993.

Rebora G., L'efficacia amministrativa nelle pubbliche amministrazioni, in Pubblica amministrazione: prospettive aziendali di analisi e di intervento, Giuffré, Milan, 1999.

Rebora G., Un decennio di riforme, Guerini e associati, Milan, 1999.

Rebora G., Meneguzzo M., Strategia delle amministrazioni pubbliche, UTET, Turin, 1990.

Tricker R., Editorial, Corporate Governance, vol. 2, n. 1, January 1994.

\section{Notes}

${ }^{1}$ The 'subsidiarity' principle is sanctioned by the Constitution. In particular for:

- 'vertical' subsidiarity you should refer to art. 118, item 1: 'administrative functions are attributed to Town Councils except if, to ensure unitary implementation, they should be assigned to Provinces, Metropolitan Cities, Regions and State, based on subsidiarity, differentiation and adequacy principles';

- 'horizontal' subsidiarity you should refer to art.118 item 4: State, Regions, Metropolitan Cities, Provinces and Town Administration encourage autonomous initiatives by citizens, individual people and associates, to carry out activities of general interest, based on the subsidiarity principle.

${ }^{2}$ The introductory parts highlight that 'many Europeans do not feel related to Union actions' and that 'the Union must launch, as of now and based on existing treaties, changes to its institutions and increase consistency between policies, to make actions and goals more visible'. This 'anxiety' over visibility and clear definition of the EU role compared to that of Member States emerges in all parts of the White Paper.

${ }^{3}$ Rebora G., (1999), Un decennio di riforme, Guerini e associati, Milan, 1999, p. 29-30.

${ }^{4}$ Rebora G., Un decennio di riforme, Guerini e associati, Milan 1999, p. 24-25.

${ }^{5}$ Meneguzzo M., Rebora G., Strategia delle amministrazioni pubbliche, UTET, Turin, 1990.

6 Rebora G., L'efficacia amministrativa nelle pubbliche amministrazioni, in Pubbliuca Amministratzione: prospettive aziendali di analisis e di intervento, Giuffré, Milan, 1984.

${ }^{7}$ Rebora G. Un decennio di riforme, Guerini e associati, Milan, 1999, p. 26.

${ }^{8}$ By 'community method' the white paper means the system governing relations between the main EU institutional bodies:

- the European Commission, as an EU proposing, executive and representative body at international level;

- the Council of Ministers and European Parliament, as decision-making, representative bodies of member states (Council) and citizens (Parliament);

- the European Court of Justice, as a body ensuring respect for legality principles.

See on the subject, the White Paper on European Community Commission Governance, page 8, Brussels, 2001.

${ }^{9}$ A need that is felt in the White paper itself, when it says that 'the way in which the Union operates at present does not permit adequate interaction in a partnership at different levels in which national governments get their regions and towns to participate fully in drafting European policies. Regions and towns often have the feeling that, despite their increased responsibility in implementing European policies, their role as elected, representative interfaces in contact with the public is not exploited', White Paper on European Community Commission Governance, page 11, Brussels, 2001. 
${ }^{10}$ In a governance model such as this, characterised by widespread, shared responsibilities, policy establishment processes and the subsequent conversion into strategies come from developing independent dialogue and sharing processes between public institutions and different interested parties. However, these must then lead, in decisions made by democratically elected institutions, to forming opinions and will, as decision responsibility always requires clear institutional imputability. The crucial role of elected assemblies clearly emerges: alongside traditional policy-making functions and control over implementation, they must organise themselves to promote and sustain systematic dialogue processes with society's different members, to continually create and update the policies that executive bodies will then have to implement. In this sense, 'decision-making body consultations should remain, so to say, permeable and receptive to issues, orientation to values, contributions and programs that reach them from a political 'public sphere' not manipulated from above'. See Habermas J., Cittadinanza politica e identità nazionale. Riflessioni sul futuro dell'Europa, in Habermas J., Morale, diritto, politica, page 124, Edizioni di comunità, Turin, 2001.

${ }^{11}$ Moore M. H., Creating Public Value, Harvard University Press, Cambridge Mass, 1995.

${ }^{12}$ White Paper on European Community Commission Governance, Brussels, 2001, p. 29.

${ }^{13}$ White Paper on European Community Commission Governance, Brussels, 2001, pp. 28-29.

${ }^{14}$ In fact, the global nature of the main problems lived by human beings - whether they be global warming, global environmental crises, global financial instability or global terrorism, automatically gives State foreign policy a multilateral view point.

${ }^{15}$ Poulantzas N., Il potere della società contemporanea, p. 109, Editori Riuniti, Rome, 1979.

${ }^{16}$ Castells M., Il potere delle identità, Università Bocconi Ed., Milan, 2003, p. 325.

${ }^{17}$ Brondoni S. M., Ouverture de 'Market-Space management', Symphonya, Emerging Issues in Management (symphonya.unimib.it), n. 1, 2002.

${ }^{18}$ Business Week, , The Future of Money, (12 June 1995).

19 Source: drafting and processing by Sandra Moog of the following sources: Government Finance Statistics Yearbook, vol. 18, Washington, IMF, 1994; International Financial Statistic Yearbook, vol. 48, Washington, IMF, 1995; The Europe World Yearbook, London Europe Publications, 1982-1985-1995; National Accounts: Detailed Tables, 1980-1992, vol. 2, Paris, OECD, 1994; OECD Economic Outlook, vol. 58, Paris OECD, 1995; World tables, 1994, The World bank, Baltimore, The Johns Hopkins University Press, 1994.

${ }^{20}$ Mattelart A., La comunicazione mondo, Il saggiatore, Milan, 1994.

${ }^{21}$ Castells M., Il potere delle identità, p. 344, Università Bocconi ed., Milan, 2003.

${ }^{22}$ Castells M., Il potere delle identità, Università Bocconi editore, Milan, 2003, p. 348.

${ }^{23}$ Final European Council of Lisbon 2000 objective. 